\title{
ГЕОЛОГІЯ І ГЕОХІМІЯ

\section{MICT}

https://doi.org/10.15407/ggcm2021.01-02

ПАВЛЮК Мирослав, НАУМКО Ігор, ПОБЕРЕЖСЬКИЙ Андрій, ЯКОВЕНКО Мирослава. Сімдесятиріччя Інституту геології і геохімії горючих копалин Національної академії наук України.

Геологія нафти і газу

ПАВЛЮК Мирослав, ЛАЗАРУК Ярослав, ШЛАПІНСБКИЙ Володимир, САВЧАК Олеся, КОЛОДІЙ Іванна, ТЕРНАВСЬКИЙ Мирослав, ГРИВНЯК Галина, ГУЗАРСБКА Любов, КОВАЛЬЧУК Наталія. Формування та критерії нафтогазоносності вуглеводневих скупчень Західного нафтогазоносного регіону України.

ГНИЛКО Олег, ГНИЛКО Світлана, КУЛЯНДА Марія, МАРЧЕНКО Романа. Тектоно-седиментаційна еволюція передової частини насувної споруди Українських Карпат.

РАДКОВЕЦЬ Наталія, ГРИГОРЧУК Костянтин, КОЛТУН Юрій, ГНІДЕЦЬ Володимир, ПОПП Ігор, МОРОЗ Марта, ГАСВСЬКА Юлія, ГАВРИШКІВ Галина, КОХАН Оксана, ЧЕРЕМІССЬКА Оксана, МОРОЗ Петро, КОШІЛЬ Леся, БАЛАНДЮК Ліна, ШАПОВАЛОВ Михайло, РЕВЕР Анастасія. Динаміка літогенезу осадових товщ фанерозою Карпато-Чорноморського регіону в аспекті їхньої нафтогазоносності.

\section{Тверді горючі копалини}

ЯКОВЕНКО Мирослава, ХОХА Юрій, ЛЮБЧАК Олександр. Перспективи використання торфів для вилучення гуматів (Львівська область).

\section{Геотехнологія}

БРИК Дмитро, ПОДОЛЬСБКИЙ Мирослав, ХОХА Юрій, ЛЮБЧАК Олександр, КУЛЬЧИЦЬКА-ЖИГАЙЛО Леся, ГВОЗДЕВИЧ Олег. Некондиційні вуглецевмісні горючі копалини та способи їхнього термохімічного перероблення...

\section{Геохімія}

ГАЛАМАЙ Анатолій, ПОБЕРЕЖСБКИЙ Андрій, ГРИНІВ Софія, ВОВНЮК Сергій, СИДОР Дарія, ЯРЕМЧУК Ярослава, МАКСИМУК Софія, ОЛІЙОВИЧ-ГЛАДКА Оксана, БІЛИК Людмила. Геохімічні особливості евапоритових формацій Євразії у контексті еволюції хімічного складу морської води протягом фанерозою.

СВОРЕНЬ Йосип. Геохімія флюїдів: інноваційне вирішення фундаментальної проблеми.

\section{Ювілеї}

ПОНОМАРЕНКО Олександр, ПАВЛЮК Мирослав. Член-кореспондент Національної академії наук України Ігор Михайлович Наумко (до 70-річчя від уродин) 


\section{GEOLOGY \& GEOCHEMISTRY

\section{CONTENTS}

https://doi.org/10.15407/ggcm2021.01-02

PAVLYUK Myroslav, NAUMKO Ihor, POBEREZHSKYY Andriy, YAKOVENKO Myroslava. The seventieth anniversary of the Institute of Geology and Geochemistry of Combustible Minerals of the National Academy of Sciences of Ukraine.

\section{Oil and Gas Geology}

PAVLYUK Myroslav, LAZARUK Yaroslav, SHLAPINSKY Volodymyr, SAVCHAK Olesya, KOLODIY Ivanna, TERNAVSKY Myroslav, HRYVNIAK Halyna, HUZARSKA Lyubov, KOVALCHUK Natalia. The formation and criteria of oil- and gas-bearing potential of hydrocarbon accumulations of the Western oil-gas region of Ukraine....

HNYLKO Oleh, HNYLKO Svitlana, KULYANDA Maria, MARCHENKO Romana. Tectonic-sedimentary evolution of the frontal part of the Ukrainian Carpathian nappe structure.

RADKOVETS Nataliya, HRYGORCHUK Kostyantyn, KOLTUN Yuriy, HNIDETS Volodymyr, POPP Ihor, MOROZ Marta, HAYEVSKA Yuliya, HAVRYSHKIV Halyna, KOKHAN Oksana, CHEREMISSKA Oksana, MOROZ Petro, KOSHIL Lesya, BALANDYUK Lina, SHAPOVALOV Mykhaylo, REVER Anastasiya. Dynamics of lithogenesis of Phanerozoic sedimentary sequence of the Carpathian-Black Sea region in the aspect of their oil- and gas-bearing potential.

\section{Solid Combustible Minerals}

YAKOVENKO Myroslava, KHOKHA Yury, LYUBCHAK Oleksandr. Prospects of using peats in the Lviv Region for humates extraction.

\section{Geotechnology}

BRYK Dmytro, PODOLSKYY Myroslav, KHOKHA Yury, LYUBCHAK Oleksandr, KULCHYTSKA-ZHYHAYLO Lesia, GVOZDEVYCH Oleh. Substandard carbon-containing raw materials and methods of their thermochemical processing.

\section{Geochemistry}

GALAMAY Anatoliy, POBEREZHSKYY Andriy, HRYNIV Sofiya, VOVNYUK Serhiy, SYDOR Dariya, IAREMCHUK Iaroslava, MAKSYMUK Sofiya, OLIYOVYCHHLADKA Oksana, BILYK Lyudmila. Geochemical features of Eurasian evaporites in the context of the chemical evolution of seawater in Phanerozoic.

SVOREN Josyp. Geochemistry of fluids: innovative solution of the fundamental problem

\section{Anniversaries}

PONOMARENKO Oleksandr, PAVLYUK Myroslav. The Corresponding Member of the National Academy of Sciences of Ukraine Ihor Mykhailovych Naumko (to 70-year anniversary). 